THE EUROPEAN JOURNAL OF LIFE WRITING VOLUME V(2016)R1-R2



\title{
Fans of the Archive: Reading Fan Letters in Richmal Crompton's Archive
}

\author{
Jane McVeigh
}

University of Roehampton

\section{INTRODUCTION}

Richmal Crompton was a British twentieth-century writer of popular children's stories. This seven minute film is about her fans, past and present, and is based in her archive at the University of Roehampton. It was made in collaboration with Archives and Special Collections and Media Services at the University of Roehampton, as well as members of the Just William Society and Richmal Crompton's family.

To see the film please click: https://vimeo.com/153080878

The archive includes fan letters from across the world, other letters, manuscripts and documents that were part of both her personal life as a daughter, sister, aunt and friend, and her professional life as a writer. One can also visit her library taken from her last home by her family, which stands alongside her desk, chair and typewriter, as well as photographs and other mementos.

Richmal Crompton wrote 'Just William' stories about an eleven year old boy called William for fifty years from 1919. She was very prolific, and published 'Just William' collections, many novels and other short stories collections. 'Just William' stories were published across Europe in many different languages and were at their height of popularity in the early to mid-twentieth century.

This film aims to bring the archive to life. To create an archival moment when the 'Just William' stories written by Richmal Crompton, displayed 
on the archive's shelves and shown in this film, original letters by her fans who wrote to her during her lifetime, and the views of her contemporary fans and family discussed in this film, come together to achieve a connection between the past and the present. It offers a chance to think about memories of childhood and the extent to which the childhood reading of her fans has gone on to influence their adult lives.

These fan letters are usually addressed to Richmal Crompton, the writer. As one of her fans makes clear in the way that he addresses her in one letter, her real name, rather than her professional one, was Richmal Lamburn. Crompton was her mother's maiden name. The letters read in this film are ones that Richmal Lamburn kept all of her life. They were important to her and we know that she wrote to some fans several times and, in at least one case, over many years. But, part of Richmal Lamburn's conversation with her fans is missing in this film. We cannot, sadly, hear a reading of what she said to them.

The letters from her fans are only some of the voices that we can hear in this archive as it also includes her correspondence with publishers, local charities, media organisations, friends and family. So, our work in archives becomes an act of remembrance, in which the details of someone else's life and our mediation as researchers develops across physical and imaginative boundaries that reinforces the performative and dialogic nature of our archival reading. 